\title{
Skolefrafall gir lav arbeidsdeltakelse
}

\section{Risikoskår for pneumoni hos barn}

\section{Et nyutviklet skåringssystem basert på kliniske funn kan hjelpe til å plukke ut hvilke barn med pneumoni som har høyest risiko for $\mathrm{d} \varnothing \mathrm{d}$.}

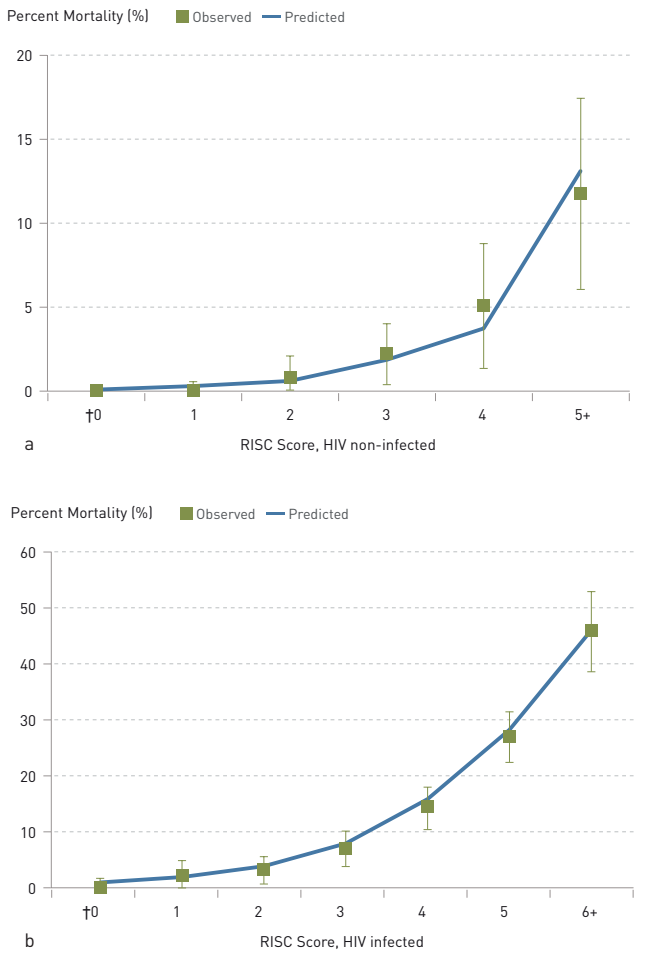

Figur 1 Korrelasjon mellom RISC-skår og mortalitet hos al hivnegative og b) hivpositive. Gjengitt med tillatelse fra PLOS ONE (2)

Pneumoni er anslått til å forårsake nær $20 \%$ av dødsfallene hos barn under fem år globalt, og særlig er dødeligheten høy hos dem under to år i fattige land. WHO-programmet Integrated Management of Childhood Illness (IMCI) (1) følges mange steder og baserer seg på enkle kliniske funn som respirasjonsfrekvens og inndragninger. De diagnostiske kriteriene er liberale for å få høy sensitivitet og maksimere antallet som får behandling, men mange steder er etterlevelsen lav (2), grunnet geografiske og sosioøkonomiske hindringer. Ved å plukke ut barna med dårligst prognose, kan behandling rettes mer målrettet mot disse.

Basert på funn hos 4148 hospitaliserte barn under to år med pneumoni har en forskergruppe utviklet det de kaller Respiratory Index of Severity in Children (RISC)-skår (2). De definerte en indeks for hivpositive barn, som i dette tallmaterialet fra Sør-Afrika hadde dødelighet på hele $17,6 \%$; og en annen indeks for hivnegative, som hadde samlet dødelighet på 1,3\%. Skåringssystemet baserer seg på fem variabler for hivnegative loksygenmetning, inndragninger, pipelyder (godt prognostisk tegn), avvisning av mat, og ernæringsstatus) og seks variabler for hivpositive loksygenmetning, inndragninger pipelyder, avvisning av mat, alder, og hivstadium). De forskjellige variablene er vektet ut ifra prediktiv verdi, slik at maksimal RISCskår blir 6 og 7 poeng for henholdsvis hivnegative og -positive. Særlig har hypoksemi stor prediktiv verdi, slik at $\mathrm{SpO}_{2}<90 \%$ gir hele 3 risikopoeng.

Det var sterk korrelasjon mellom RISCskår og mortalitet (fig 1). Dersom ingen eller få risikofaktorer er til stede er dødeligheten lav, men den stiger nærmest logaritmisk med antall risikofaktorer.

\section{Kristoffer Brodwall}

kristoffer.brodwall@gmail.com

Avdeling for internasjonalt samarbeid

Haukeland universitetssykehus

\section{Litteratur}

1. WHO. Multi-country evaluation. Integrated management of childhood illness. www.who.int/ imci-mce/ (17.4.2012).

2. Reed C, Madhi SA, Klugman KP et al. Development of the Respiratory Index of Severity in Children (RISC) score among young children with respiratory infections in South Africa. PLoS ONE 2012; 7 e27793.

\section{Skolefrafall og dårlig helse i ung- domstiden gir dårligere integrering i arbeidslivet i ung voksen alder. Dette viser en ny norsk studie.}

Nesten 9000 ungdommer i alderen 13-19 år i Nord-Trøndelag fylte ut et spørreskjema om egen helse (Ung-Hunt1, 1995-97) og ble fulgt med andre datakilder om mottak av langvarige trygdeytelser fra 19-28 års alder (1). Langvarige medisinske ytelser ble definert som mottak av sykepenger, rehabiliteringspenger, attføringspenger eller uføretrygd i mer enn et halvt år per kalenderår, mens ikke-medisinske ytelser var mottak av dagpenger eller sosialstønad.

$17 \%$ av deltakerne hadde ikke fullført videregående skole ved fylte 24 år. I løpet av fem år (24-28 års alder) hadde nesten halvparten av dem som ikke hadde fullført skolegang, mottatt langvarige ytelser, mot rundt $15 \%$ blant dem som hadde fullført. De fleste langvarige fravær skyldtes forhold som ga medisinske ytelser.

Ungdom med dårlig selvrapportert helse hadde betydelig mer skolefrafall. Dårlig helse bidro til betydelig høyere fravær fra arbeidslivet på både medisinsk og ikke-medisinsk grunnlag. Dette kunne ikke forklares med selve skolefrafallet alene eller med foreldres utdanningsnivå. Nesten $60 \%$ av ungdom med dårlig helse og som ikke hadde fullført videregående skole mottok langvarige ytelser i alderen 24-28 år, mot 16\% av ungdom med god helse og fullført utdanning.

Mange unge mennesker fullfører ikke videregående skole. Studien viser at skolefrafall er en klar indikator på fremtidig sårbarhet for en vellykket inngang $i$ arbeidsmarkedet. Dårlig helse i ungdomstiden øker også risikoen for sosial ekskludering i overgangen fra ungdomstid til voksenliv. Et ensidig søkelys på arbeidsmarkedet og videregående opplæring er ikke nok for å forstå unge som sliter med arbeidsintegrering, dårlig helse eller begge deler. Sviktende integrering av ungdom med svak helse må tas på alvor.

\section{Karin De Ridder}

karin.de.ridder@ntnu.no

Institutt for samfunnsmedisin

Norges teknisk-naturvitenskapelige universitet

\footnotetext{
Litteratur

1. De Ridder KA, Pape K, Johnsen R et al. School dropout: a major public health challenge: a 10year prospective study on medical and non-medical social insurance benefits in young adulthood, the Young-HUNT 1 Study (Norway). J Epidemiol Community Health 2012; e-publisert 6.2.2012.
} 